experiments have a more definite application both to civil and service flying, where the question of the proper balance between quantity of fuel carried-to the exclusion of useful load-and the necessity for landing for further supplies, is essentially a practical one, peculiar to the geographical conditions in different parts of the world. These experiments should also further the development of the compression-ignition heavy-oil engine, the smaller specific fuel consumption of which makes it particularly applicable in this case.

\section{Future of Lighter-than-Air Craft}

THE announcement that the Secretary for the U.S. Navy will oppose any further construction of airships to replace the wrecked Macon presages the end of large rigid airship activities in that country. Germany is now the only country, so far as is known, to continue experiments with these craft in increasing sizes, the new larger Zeppelin, to be called the Hindenburg, being now near completion. It is significant that Dr. Fckener of the Zeppelin Company has succeeded where others have failed, probably because with faith and perseverance he has acquired that kind of knowledge and experience in design, and assembled a staff skilled in the technique of construction, maintenance and handling, which can only result from practical experience. Germany has now been building large airships continuously since 1910, and even up to 1914 claimed to have flown 80,000 miles and carried more than 37,000 passengers. The present Graf Zeppelin, launched in 1928, has crossed the Atlantic 62 times without serious mishap. The only large airship in the United States that is still in an airworthy condition, the Los Angeles, is a Zeppelin type built at Friedrichshafen.

IT is claimed nowadays that for long-distance commercial flying the airship is threatened by the large flying boat, which unquestionably has superior speed, but has not yet attained a comparable range. The latest projected flying boats only claim to be able to fly the Atlantic non-stop with a favourable wind. As a naval scout, if it can be protected from attack, the airship is still unrivalled. It can patrol trade routes far outside the range of aeroplanes, and its vision must be greater than any surface cruisers. It is also reasonably independent for action of the movements of its own surface vessels, a decided drawback of aeroplanes carried by the fleet.

\section{Fundamentalism Undefeated}

A CABLE message dated February 20 from New York which has appeared in The Times states that on the previous day the House of Representatives of Tennessee defeated a motion to repeal the State law which prohibits the teaching of any theory that man is descended from a lower order of animals. The vote against repeal was 67 to 20 , and the opposition to the repeal was led appropriately by the oldest member of the House, who opened his case by reading the first chapter of Genesis. It will be remembered that about ten years ago a young teacher of biology, J. T. Scopes, was convieted and fined at Dryton under this law. The case aroused great controversy in the United States, and was outstanding because of the eminence and the oratory of the counsel employed on each side. Perhaps it was outstanding also as a picture of the simple faith which holds that truth can be decided by lawyer's arguments, and that scientific fact can be settled by majorities. Fundamentalism is by no means dead in Great Britain, but with the growth of knowledge it is dying.

\section{Musk-Rats in Scotland}

SINCE the musk-rat campaign was commenced by the Department of Agriculture for Scotland, in October 1927, the official trappers have killed 945 individuals. To this must be added 60 killed by private persons, a total of 1,085 , the progeny of five females and four males which escaped from an enclosure in Perthshire in 1927. Even the artificial pond on Gleneagles Golf Course has yielded five since the beginning of November 1934 (Scottish Naturalist, 1934, p. 11). As a rule, the traps were laid at the mouth of a burrow, and a remarkable fact is that they did much more damage to other wild ereatures than to the musk-rats themselves. Mr. T. Munro, who supervised the work, records the death in traps set for musk-rats of 1,745 brown rats, 2,305 watervoles, 57 weasels, 36 stoats, 2,178 moorhens, 101 ducks, and a miscellaneous collection of birds, including amongst others 23 seagulls, 13 redshanks, 28 snipe, 15 blackbirds and a solitary kingfisher-a list of misadventures which runs to 6,587 items. It is possible that this very considerable slaughter cannot be avoided, but apart from the brown rats the majority of the wild creatures slain are harmless, if not even useful from the human point of view, so that every effort should be made to confine the work of the traps to the pests they are meant to capture.

\section{Moving Biological Diagrams}

MANY of the living processes of organisms can be illustrated most effectively by cinema films taken through the microscope, and with Mr. Walt Disney's technique, diagrams could be shown in the same way for educational purposes. The American Genetic Association has applied this principle in publishing "Biological Movie Booklets" to illustrate cell division, fertilisation and meiosis, and it proposes to deal later with the more intricate processes of heredity in Drosophila, crossing-over and so forth (Biological Movie Booklets. Vol. 1 : Normal Cell Division. By Clyde E. Keeler. Pp. 46. Vol. 2 : Maturation of Sperm. By Clyde E. Keeler. Pp. 94. Vol. 6 : Fertilization. By Clyde E. Keeler. Pp. 65. Washington, D.C. : American Genetic Association, 1929. 3 vols., 1.50 dollars). Successively releasing the leaves of the booklets brings these dead diagrams to life, and for those who have not learnt to make the mental translation of diagrams into movement the effect should be improving. For those who have passed this stage the effect is still amusing, provided that the leaves are turned over quickly. Taken separately, however, the figures seem to be drawn, not from life but from an early or popular textbook. The 
descriptive text is correct for 1908. The draughtsmanship is not expert and the drawings should have been reduced from a larger size to conceal its defects. If a future generation is to learn its biology this way, it is to be hoped that the publishers will take their task more seriously and remedy these shortcomings.

\section{Acquisitions at the British Museum (Natural History)}

ReCent acquisitions by the Department of Zoology include a specimen of the frilled shark (Chlamydoselachus) caught by a trawler off the west of Ireland. This is the first occasion on which this species has occurred in British waters. It was first discovered off the Japanese coasts. The frilled shark is of great interest on account of the many primitive characters which it possesses. The mouth is at the end of the snout, instead of being underhung as in most living sharks. There are six gill openings on each side instead of the usual five, and the teeth are of a curious comb-like shape. The body is much more slender and eel-like than in other sharks, and in several ways it approaches some of the very ancient types of fossil shark-like fishes. Through the generosity of the trustees of the Salisbury, South Wilts and Blackmore Museum, the Department of Geology has received a large number of fossil invertebrates and fishes, forming part of the collection made by the late Dr. H. P. Blackmore from the Chalk in the vicinity of Salisbury. A further valuable instalment of 488 specimens of Swiss minerals, representing 59 carefully recorded localities, collected by himself, has been presented by Mr. F. N. Ashcroft to the Department of Minerals.

THE Department of Botany has received a bequest of Mr. T. J. Foggitt's British herbarium. This numbers 4640 sheets of well-gathered and beautifully preserved plants. Mr. Foggitt was a well-known Yorkshire botanist, the son of the T. J. Foggitt who collaborated with J. G. Baker in the formation of the Botanical Exchange Club which brought Thirsk into botanical prominence in the sixties of last century. The herbarium is rich in Yorkshire plants, and is a welcome addition not only for this but also on account of the large number of extremely rare plants it contains. The Siamese collection of Dr. A. Marcan has been purchased. It contains abundant material of 2772 numbers including several co-types. It has been named for the most part by the late Prof. W. Craib and Dr. A. Kerr. The collection forms a valuable addition to the Department which is weak in Siamese plants. A further set of Dr. H. Schlieben's Tanganyika plants numbering 146 has been purchased. The first two fascicles of Lundell and Nannfeldt's "Fungi exsiccati suecici praesertim Upsalienses" has been presented by the Elias Fries Committee. This exsiccata is of especial interest as it consists mainly of fungi collected in the neighbourhood of Uppsala, a region made famous by the classical works of Elias Fries.

\section{Rural Electrification in Russia}

ONE of the results of the first five-year plan is to change fundamentally the character of farm work in the U.S.S.R. Instead of a million small holdings, there are now only some thousands of large collective agricultural and pastoral farms. Horse traction and manual labour are rapidly being replaced by the mechanical tractor and electrically driven machines and implements. Electrification is the key-note of the industrial reorganisation of the country. In the Electrical Review of February 22, G. Shapiro gives a description of some of the new agricultural and dairy farming methods. Experiments on electrical haulage and electric tractors for ploughing have proved most satisfactory. The electric tractors used for ploughing were usually converted mechanical tractors in which the internal combustion engines had been replaced by electric motors. The results show a considerable saving in working expenses. Excellent results are being obtained with electric threshing, which is developing very rapidly. These machines are produced in Kharkov, and are driven by electric motors. Electrically driven machines have also been successfully experimented on in connexion with vineyards, tea plantations and cotton fields. In dairy farms, electricity will be used for milking, cleaning the animals, preparing food, water pumping, ventilation, butter making, cheese making and lighting. Pig farms and poultry farms also take an appreciable electric load. Researches are being made on the heating of the soil and the influence of light and various rays on seeds, roots and poultry and animal breeding. By the end of the second five year plan (1937), it is anticipated that about 30,000 stations will be threshing electrically and will cover a sowing area of about 30 million acres.

\section{Aerodrome Lighting for Night Flying}

OwING to the steady increase in the number of passengers and in the volume of the mails carried by aeroplanes, the proper lighting of aerodromes has become of great importance. In the G.E.C. Journal of November, Mr. W. A. Villiers describes the equipment produced by the General Electric Company for this purpose. The problem is to give the pilot of an aeroplane flying on a dark night the guidance he requires to make a safe landing. In many cases at the present time, aerodromes are only a few miles apart; he must therefore be able to identify the place with certainty. This is done by means of a beacon. The light must be visible in all weathers, but must not be dazzling. The colour and character of the light should be different from that given by neighbouring beacons. The beacon is in the shape of a truncated cone about $14 \mathrm{ft}$. high, formed of six hairpin-shaped neon tubes giving the usual red neon colour. It has low intrinsic brilliancy, but in favour. able weather conditions can be seen at a distance of 50 miles. The identification is usually effected by making it flash in Morse characters the initial letter of the aerodrome. The boundary of the landing place is marked out by electric lamps inside orange glass globes. All landings are made against the wind as this direction gives the safest landing. The landing ground should always be flood-lighted, the space being so large that even the fastest aeroplane does not overrun the lighted area. Nine Osram lamps 